\title{
Types and Duration of Unemployment in Kosovo
}

\author{
Nagip Skenderi \\ Asstt.Prof., University of Prishtina, Faculty of Economics \\ Email: nagipskenderi@hotmail.com \\ Adhurim Uka \\ University of Prishtina, Faculty of Economics \\ Email: adhurim.uka@uni-pr.edu
}

Doi:10.5901/mjss.2015.v6n3p453

\begin{abstract}
The unemployment rate remains one of the most important economic indicators of a country as the employed themself are the most important part of any economy. In Kosovo, such a topic remains one of the most debated problems since the unemployment rate hits 30\% (KAS, 2012), a rate much higher than in any OECD member. Making a clear distinction of the types of unemployment that a country faces is crucial since different ALMP's are required to target each of the types. Hence, we discuss the different types of unemployment that a country may face and we analyze if such types are suitable for describing the unemployment rate in Kosovo and if so, what policies are required to target them. We then return to the duration of unemployment and we discuss the reasons for the long-term unemployment in Europe. We then analyze if such reasons are suitable for describing the long-term unemployment in Kosovo.
\end{abstract}

Keywords: Unemployment, structural, long-term, causes, policies.

\section{Introduction}

Speaking about the consequences that it has, unemployment may not be an unknown problem. But when it comes to analyzing the types of unemployment, its causes, its natural rate and similar problems, it remains a challenging one.

This paper tries to explain how different types of unemployment affect the Kosovo's economy. Each economy faces different types of unemployment, consequently, different policies are required to deal with them. The wrong policy, not only will not solve the problem, but it may deepen the problem further. Therefore, the first important step in this field remains the identification of the causes of unemployment so that the governments can pick up the right policy that will make a difference. That is very important in Kosovo, where the unemployment rate goes up to 30\% (KAS, 2013).

For such a purpose, the authors have used standard labor economics textbooks for the various technical definitions explained. Also, the data used in this paper were collected from official organisations such as Kosovo's Agency of Statistics (2012) which is by far the most comprehensive study of the labor market in Kosovo. Thus, the paper combines standard definitions and official data in order to explain the situation to a broader range of economists, politicians and the general public as well.

In the first part of this paper, we briefly discuss the rate of unemployment, the way of measuring it and its restrictions. We conclude that if the labor market situation is assessed solely by this indicator, we will have a distorted picture of it. Then we analyze the types of unemployment encountered in Kosovo and what policies are required to target them.

At the end, we return for the duration of unemployment in Kosovo, where we primarily give a conclusion of the international debate on the causes of long-term unemployment in Europe and then analyze the causes of this type of unemployment in Kosovo and eventually treat some of its consequences.

\section{The Rate of Unemployment and the Labor Market in Kosovo}

For objective reasons, there is a considerable gap between the usage of the work factor as an abstract concept and the unemployment rate as a statistic. This is so because a complete measurement of the phenomenon of unemployment is impossible. Thus, in most countries the unemployment rate is given as a proportion between the number of those actively 
seeking a job and who cannot find one and the total number of the workforce, that consists of skilled persons aged 16-64 years.

However, this measurement has some limitations that make it unsuitable for extracting decisive estimates and conclusions on the state of the labor market.

The first of these limitations is the exclusion of discouraged workers (Qiriçi, 2005). These include individuals who have given up on looking for a job for various reasons. In Kosovo, discouraged workers make up to $14.8 \%$ of the workforce (KAS, 2013). So there are approximately 176,100 people who have given up looking for work because they believe no jobs are available. This is very important because in a potential economic success, this force can be activated and serve as a resource of work.

Under this understanding, in Kosovo, the problem remains in the growing rate of inactivity. From 2009 to 2012 the unemployment rate dropped to $14.5 \%$, but participation in the workforce has also fallen to $11.2 \%$. A large proportion of inactive persons, $17.7 \%$ of them, are justified with household duties or several other similar reasons and can be activated in the labor market either with the opening of new jobs or with other specific policies.

Part-time work remains one of the other problems. In this case, workers may fail to reach their potential through their work. In Kosovo, it was reported that $11.1 \%$ of employees work part time while $66.7 \%$ of them work as such without their consent.

A controversial issue remains the 'hidden' unemployment in the public sector or public enterprises, partly inherited from the previous communist system. We say that a hidden unemployment exists when the removal of an employee from his job does not affect the overall performance of the organization. A doubt for such a situation in Kosovo arises from the fact that the public sector is responsible for $33 \%$ of (MLSW, 2012) the employments in the country and the performance of this sector is estimated to be poor.

As a conclusion, the unemployment rate does not fully reflect the problems that the society faces (Ehrenberg \& Smith, 2012). These are some of the factors that should be considered when assessing the rate of unemployment in Kosovo. But generally speaking, the rate of unemployment, without being considered as an absolute indicator, represents an important indicator in the framework of labor market indicators.

\section{Types of Unemployment in Kosovo}

The unemployment rate in a country is not necessarily bad in itself. This depends greatly on the type of unemployment in that country. Societies are usually more concerned if a few individuals are unemployed for a long time than if many individuals move quickly from one job to another (Ehrenberg \& Smith, 2012).

Types of unemployment that economists usually highlight are four:

1) Frictional unemployment, which implies that some people are between jobs. Some leave a job to find a better one, others have just entered the labor market and didn't find a job yet and so forth. This type of unemployment occurs because of asymmetric information and as such firms and workers need time to adapt. In fact, if they would find one another immediately or if workers would stay in a job for life, this type of unemployment would not exist. That is why it is impossible. In reality, frictional unemployment is necessary and useful because job search makes more efficient allocation of resources. To reduce this type of unemployment, government can expand or modernize the employment offices to facilitate information exchange between workers and firms.

2) Structural unemployment is a result of the changes in the structure of the economy. Put in other words, in the economy, some sectors may be declining while others may be growing. For example, in developing countries the industrial sector is declining while the services sector is growing. This appears the problem of 'skills mismatch' or labor demand and supply mismatch, because workers need time to adapt to the new jobs.

In transition economies, the conversion from a centralist system to a market economy is accompanied by structural changes in the economy (Borjas, 2005). On the spur of the moment, the production is oriented from the heavy industry towards the light industry or the service sector. In Kosovo, with a predominantly young population, impacts of these and other shocks that occurred 10-20 years ago may have faded already.

An indicator to assess whether unemployment is structural is the probability of individuals with higher education to get a job (Hobijn, 2011). This is so because it is considered that if they have a problem to find a job, then the abilities of workers can't be the problem. Also, worth noting is the fact that in Kosovo many of the workers work in the manufacturing sector, trade and construction.

Given these indicators, we may reason out that unemployment in Kosovo is not purely of structural reasons, not denying the fact that this form of unemployment comes out in any normal economy. 
3) Seasonal unemployment occurs when a job can't continue during the entire time period, usually a year, due to lack of demand for manufactured goods, weather conditions and so on. In Kosovo, due to the large number of employees in agriculture, trade and construction, differences in unemployment during the year are considerable.

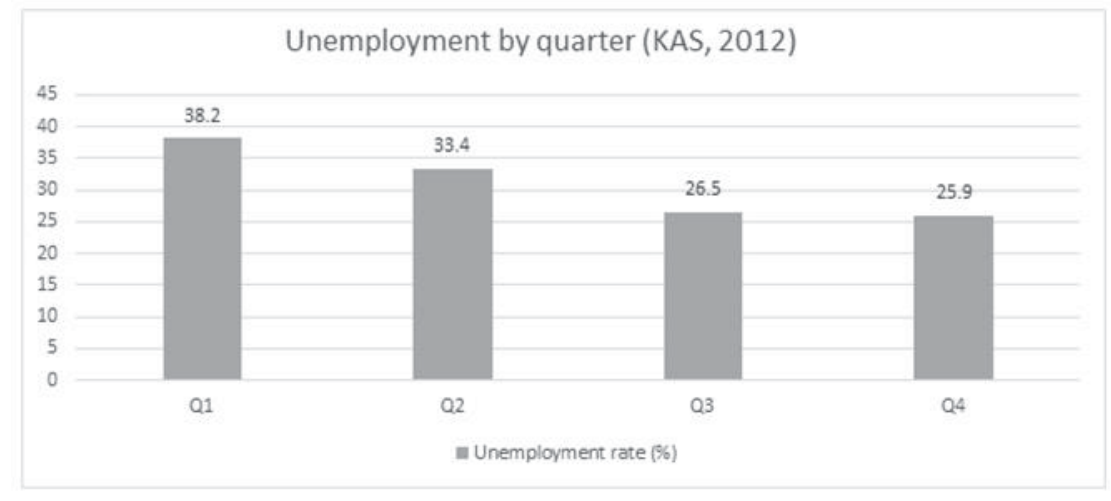

Figure 1. Seasonal unemployment in Kosovo (KAS: 2012).

Such unemployment is somewhat predictable and probably not harmful, for employees who work seasonal jobs receive higher wages as a compensation. A study in the US found that seasonal workers in agriculture receive an average salary $10 \%$ higher than those who work on farms throughout the year (Ehrenberg \& Smith, 2012).

4) Cyclical unemployment or the lack of demand for labor is the most problematic type of unemployment. In situations when the economy is in decline, firms' profits fall and while wages are rigid-downwards, unemployment results. In a full competition model, wages would fall and firms wouldn't start firing. Another scenario occurs when economic growth is likewise sluggish and as such does not allow for creating decent jobs. In both cases, there are individuals who are interested and have the ability to work, but the firms don't provide jobs for them.

In the case of Kosovo, the second scenario is present. According to an estimate, since 2010, Kosovo needs an average economic growth of $10 \%$ per year to reach Albania after 10 years, assuming that it will grow by $5.5 \%$ per year until then (UNDP, 2012). Currently, economic growth is less than half of that. In a tough business environment with many administrative procedures, low security, high interest rates and a multitude of other problems, firms face many difficulties to offer stable jobs.

\section{Duration of Unemployment in Kosovo}

$59.8 \%$ of the unemployed in Kosovo remain so for more than 12 months (KAS, 2013). We mentioned earlier that some of those who once were seeking a job are now counted as inactive since they have given up looking for work because they believe that they can't find one. These are certainly facing long periods of unemployment.

\subsection{The debate over the long-term unemployment}

One of the most challenging questions in economics remains that how some workers remain unemployed for a long time. Although not a single theory comes up with a convincing explanation of this problem, it seems that this problem is different in different countries or in different situations.

Many factors can affect both the duration of unemployment as most of the research suggests (Krugman, 1994). For example, in Europe, unemployment benefits, the rules that impede firing/hiring, maximum hours and minimum wages are seen by many economists as the main causes of a rising long-term unemployment.

The inquiry arises, in an economy like that of Kosovo's without benefits for the unemployed, with few labor market regulations accompanied by a high level of informality, which are the causes of long-term unemployment?

Broadly understood, the long period of economic stagnation that pretty much started from the time of workexpulsion from the 90s, the destruction of industry, in particular of manufacturing during the war are associated with a period of uncertainty and transition that was not able to create enough places for work to improve the economy from the 
shocks led to the enormous length of unemployment (RI 2003).

\subsection{The consequences of long-term unemployment}

A stable unemployment rate as in Kosovo leaves many consequences for the economy. In addition to the opportunity costs of not using the human capital, the eventual violence and insecurity, as well as the problems encountered by an unemployed individual, it is worth to mention some other problems.

The foremost is the deprivation of a skilled work force. Former socialist countries were initially struck by the problem of the 'mismatch of skills' (Hoti, 2003), a problem which has risen as a result of the fact that many skills were then not necessary due to the shifting labor market - the transition from several sectors into others. This can bear an impact, especially in the older generations, because changes have occurred in their time. They (i.e. Aged approximately 45-60 years) also may have given up looking for work. On the other hand, 126,200 young people (16-24) who neither work nor go to any training program remains disturbing (KAS, 2013).

Secondly, studies indicate that there is an inverse relation between the level of wages and the rate of unemployment (Ehrenberg \& Smith, 2012). When unemployment is low wages are high and vice versa. This connection is mapped by the wage curve.

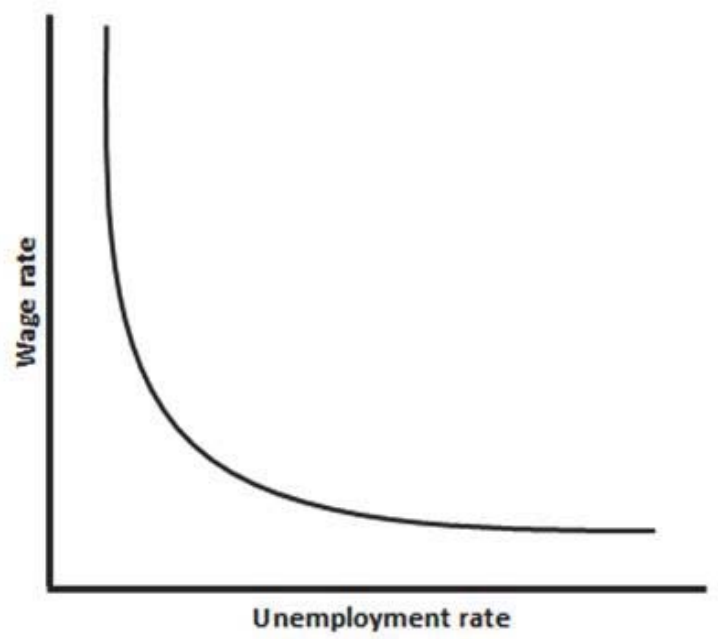

Thus, long-term unemployment affects the unemployed by hindering their current hiring chances and by cutting their income. Both of these problems have macroeconomic impact on the level of income in the economy and in other indicators consequently.

\section{Conclusions}

As we mentioned earlier the unemployment rate may not fully reflect the situation of the labor market in a country. The exclusion of discouraged workers and the growing rate of inactivity, then the inclusion of 'hidden' unemployment and that of part-time work are some of the main reasons for this. That said, the unemployment rate provides us with some useful insights about the labor market.

As for the types of unemployment in Kosovo, we make the argument that frictional unemployment is always to be found in an economy. Structural changes are not the main cause of unemployment, although Kosovo's economy passed through a severe transition. We make such a conclusion for several reasons, including the fact that the workers work primarily in sectors which don't have any "barriers of entry". Also, those who earn a degree have a much higher chance of employment than those who don't. Mentioning the fact that seasonal workers usually get higher compensation, seasonal unemployment is present due to the large number of employees in agriculture, trade and construction.

So finally, we associate the high rate of unemployment with the lack of economic growth during the last two decades. The unstable political situation made it unlikely for major investments in the economy. Also, the persistent high rate of unemployment may worsen itself by itself by hindering the hiring chances for the unemployed. 


\section{References}

Borjas, G. (2005). Labor Economics; 3rd ed. New York: McGraw-Hill Irwin.

Ehrenberg, R. G., \& Smith, R. S. (2012). Modern Labor Economics: Theory and public policy; 11th ed. Prentice Hall.

Hobijn, B. (2011). Recent College Graduates and the Labor Market. FRBSF Economic Letter.

Hoti, A. (2003). Human Capital and Unemployment in Transition Economies: The Case of Kosova. From Transition to Development: Globalisation and the Political Economy of Development in Transition Economies. Sarajevo: Faculty of Economics.

KAS. (2013). Rezultatet e anketës së fuqisë punëtore 2012 në Kosovë. Prishtina: Kosovo Agency of Statistics.

Krugman, P. (1994). Past and Prospective Causes of High Unemployment. Reducing Unemployment: Current Issues and Policy Options. Kansas City: Federal Reserve Bank.

MLSW. (2012). Puna dhe punësimi. Prishtina: Ministry of Labour and Social Welfare.

Qiriçi, S. (2005). Ekonomiksi i punës. Tirana.

RI. (2003). Tregu i punës dhe papunësia në Kosovë. Prishtina: Riinvest Institute.

UNDP. (2012). Raporti i Zhvillimit Njerëzor në Kosovë 2012: Sektori Privat dhe Punësimi. Prishtina: UNDP. 